\title{
Populations of Helicoverpa zea (Boddie) in the Southeastern United States are Commonly Resistant to Cry1Ab, but Still Susceptible to Vip3Aa20 Expressed in MIR 162 Corn
}

\author{
Ying Niu ${ }^{1}$, Isaac Oyediran ${ }^{2}$, Wenbo Yu ${ }^{1}$, Shucong Lin ${ }^{1}$, Marcelo Dimase ${ }^{1}$, Sebe Brown ${ }^{3}$, \\ Francis P. F. Reay-Jones ${ }^{4}$ D , Don Cook ${ }^{5}$, Dominic Reisig ${ }^{6}$, Ben Thrash ${ }^{7}$, Xinzhi Ni ${ }^{8}$, Silvana V. Paula-Moraes ${ }^{9}$, \\ Yan Zhang ${ }^{2}$, Jeng Shong Chen ${ }^{2}$, Zhimou Wen ${ }^{2}$ and Fangneng Huang ${ }^{1, *(D)}$
}

check for

updates

Citation: Niu, Y.; Oyediran, I.; Yu, W.; Lin, S.; Dimase, M.; Brown, S.; Reay-Jones, F.P.F.; Cook, D.; Reisig, D.; Thrash, B.; et al. Populations of Helicoverpa zea (Boddie) in the Southeastern United States are Commonly Resistant to Cry1Ab, but Still Susceptible to Vip3Aa20 Expressed in MIR 162 Corn. Toxins 2021, 13, 63. https://doi.org/ $10.3390 /$ toxins 13010063

Received: 26 November 2020 Accepted: 12 January 2021 Published: 15 January 2021

Publisher's Note: MDPI stays neutral with regard to jurisdictional clai$\mathrm{ms}$ in published maps and institutional affiliations.

Copyright: (C) 2021 by the authors. Licensee MDPI, Basel, Switzerland. This article is an open access article distributed under the terms and conditions of the Creative Commons Attribution (CC BY) license (https:// creativecommons.org/licenses/by/ $4.0 /)$.
1 Department of Entomology, Louisiana State University Agricultural Center, Baton Rouge, LA 70803, USA YNiu@agcenter.lsu.edu (Y.N.); wyu14@lsu.edu (W.Y.); slin9@lsu.edu (S.L.); msdimase@agcenter.lsu.edu (M.D.)

2 Syngenta Crop Protection LLC, Research Triangle Park, NC 27709, USA; isaac.oyediran@syngenta.com (I.O.); yan.zhang@syngenta.com (Y.Z.); eric.chen@syngenta.com (J.S.C.); zhimou.wen@syngenta.com (Z.W.)

3 Dean Lee Research Station, Louisiana State University Agricultural Center, Alexandria, LA 71302, USA; SBrown@AgCenter.lsu.edu

4 Department of Plant and Environmental Sciences, Clemson University, Florence, SC 29506, USA; freayjo@clemson.edu

5 Delta Research and Extension Center, Mississippi State University, Stoneville, MS 38776, USA; DCook@drec.msstate.edu

6 Vernon G. James Research and Extension Center, North Carolina State University, Plymouth, NC 27962, USA; ddreisig@ncsu.edu

7 Lonoke Extension Center, University of Arkansas, Lonoke, AR 72086, USA; bthrash@uaex.edu

8 Crop Genetics and Breeding Research, USDA-ARS, Tifton, GA 3173, USA; xinzhi.ni@usda.gov

9 Entomology \& Nematology Department, West Florida Research and Education Center, University of Florida, Jay, FL 32565, USA; paula.moraes@ufl.edu

* Correspondence: fhuang@agcenter.lsu.edu; Tel.: +1-225-578-0111

Abstract: AbstractsThe corn earworm, Helicoverpa zea (Boddie), is a major pest targeted by pyramided Bacillus thuringiensis (Bt) corn and cotton in the U.S. Cry1Ab is one of the first insecticidal toxins used in Bt crops, while Vip3A is a relatively new toxin that has recently been incorporated into Cry corn with event MIR 162 and Cry cotton varieties to generate pyramided Bt traits targeting lepidopteran pests including $H$. zea. The objectives of this study were to determine the current status and distribution of the Cry1Ab resistance, and evaluate the susceptibility to Vip3Aa20 expressed in MIR 162 corn in H. zea in the southeastern U.S. During 2018 and 2019, 32 H. zea populations were collected from non-Bt corn (19 populations), Cry corn (12), and Cry/Vip3A cotton (1) across major corn areas in seven southeastern states of the U.S. Susceptibility of these populations to Cry $1 \mathrm{Ab}$ and Vip3Aa20 was determined using diet-overlay bioassays. Compared to a known susceptible insect strain, $80 \%$ of the field populations were 13 - to $>150$-fold resistant to Cry $1 \mathrm{Ab}$, while their response to Vip3Aa20 ranged from $>11$-fold more susceptible to 9-fold more tolerant. Mean susceptibility to each Bt toxin was not significantly different between the two groups of the populations collected from non-Bt and Bt crops, as well as between the two groups of the populations collected during 2018 and 2019. The results show that resistance to Cry1Ab in $H$. zea is widely distributed across the region. However, the Cry1Ab-resistant populations are not cross-resistant to Vip3Aa20, and H. zea in the region is still susceptible to the Vip3Aa20 toxin. Vip3Aa20 concentrations between 5 and $10 \mu \mathrm{g} / \mathrm{cm}^{2}$ may be used as diagnostic concentrations for susceptibility monitoring in future. Additional studies are necessary to elucidate the impact of the selection with Bt corn on resistance evolution in $H$. zea to Vip3A cotton in the U.S.

Keywords: corn earworm; Bt susceptibility; Cry1Ab; Vip3A; resistance monitoring

Key Contribution: Susceptibility of $32 \mathrm{H}$. zea populations collected from non-Bt and Bt crop fields in the southeastern United States to Cry1Ab and Vip3Aa20 toxins was determined using diet-overlay 
bioassays. The results show that $H$. zea populations in the region are commonly resistant to Cry1 $\mathrm{Ab}$, but still susceptible to Vip3Aa20 expressed in MIR 162 corn.

\section{Introduction}

The corn earworm, Helicoverpa zea (Boddie), is a cross-crop target pest of both Bacillus thuringiensis (Bt) corn and cotton in the U.S. [1,2]. Corn and cotton are usually planted in close proximity in the southern U.S. (often called the U.S. Cotton Belt) where predominant areas of the two crops are planted with varieties containing Bt transgenes [3]. The typical host progression of $H$. zea in the southern U.S. is that the first generation develops on wild hosts, the second generation primarily feeds on corn, and the subsequent 2 to 3 generations switch to cotton and other hosts before overwintering [2,4]. In addition, some of the populations originating from the Cotton Belt migrate into the northern regions where they can cause damage to many crops and vegetables [5]. Because $\mathrm{Bt}$ toxins produced in transgenic corn and cotton are similar, H. zea in the southern U.S. is subjected to resistance selection for multiple generations each year. The cropping system plus the similarity of Bt toxins expressed in corn and cotton creates an ideal environment for resistance development in H. zea [1,4].

During recent years, widespread field resistance to Cry1A.105/Cry2Ab corn and Cry1Ac/Cry2Ab cotton in $\mathrm{H}$. zea has been documented in the U.S. [1,6-9]. In its early commercial use, the single-gene Cry1Ab corn (e.g., YieldGard ${ }^{\circledR}$ Corn Borer) was marginally effective against $H$. zea [10,11]. By 2012-2013, field trials in North and South Carolina showed that Cry1 Ab corn was no longer efficacious against $H$. zea and the control failures were believed to be most likely due to resistance development [12]. In Louisiana, Cry1 Ab corn also failed to control H. zea during 2017 (FH, unpublished data, personal communication). Unfortunately, there were no follow-up studies to further document the Cry1 $\mathrm{Ab}$ resistance.

Vip3A is an insecticidal toxin produced during the vegetative growth stages of $\mathrm{Bt}$ bacteria [13]. Compared to Cry toxins, Vip3A has a distinct mode of action and thus cross-resistance between Vip3A and Cry toxins is unlikely [13-18]. Vip3A, as two variants of a native Vip3Aa1, was first registered for commercial use in Bt cotton (e.g., VipCot ${ }^{\mathrm{TM}}$ cotton) in 2008 and Bt corn (e.g., MIR 162) in 2011. The Vip3A gene used in cotton is Vip3Aa19, while it is Vip3Aa20 in corn [19,20]. Vip3Aa19 and Vip3Aa20 are very similar in gene structure, both sharing $>99.7 \%$ amino acid sequence identity with the native toxin and having the same mode of action [19]. Corn and cotton varieties expressing Vip3A toxin are highly effective in $\mathrm{H}$. zea control [21-25]. However, the areas planted to Vip3A-expressing crops had been limited until recently [26]. The widespread occurrence of Cry1/Cry2 resistance in $\mathrm{H}$. zea greatly encourages the use of Vip3A crops, especially in cotton in the U.S. Additionally, field resistance of the fall armyworm, Spodoptera frugiperda (J.E. Smith), to Cry1F corn has become widespread in the Americas [26-30]. Vip3A corn has also become an important tool for managing the Cry1F-resistant $S$. frugiperda, especially in South America [31]. Therefore, preservation of the susceptibility to Vip3A in these target pests is crucial for the continued success of transgenic Bt plant technology.

Resistance monitoring of field insect populations is a fundamental component of effective resistance management programs [4,32]. Data on geographical susceptibility of pest populations are essential in resistance monitoring. Unfortunately, information on geographical susceptibilities of $H$. zea populations to Cry1 Ab and Vip3A is limited, with only two peer-reviewed studies related to Cry $1 \mathrm{Ab}$ susceptibility established before and during the early commercial use of Cry1A crops $[33,34]$. The only peer-reviewed study related to $H$. zea susceptibility to Vip3Aa20 is from Brazil [31]. Another early study in the U. S. evaluated the susceptibility of H. zea to Vip3Aa19 expressed in Bt cotton [20]. In the current study, $32 \mathrm{H}$. zea populations were collected from non-Bt corn (19 populations), Cry corn (12), and Cry/Vip3A cotton (1) fields across major corn production areas in seven 
states of southeastern U.S. Susceptibility of these populations to Cry1Ab and Vip3Aa20 was determined using diet-overlay bioassays [8]. The objectives of the current study were to determine the current status and geographic distribution of Cry1 $\mathrm{Ab}$ resistance, and monitor Vip3Aa20 susceptibility in H. zea in the region. Information generated from this study will be useful in developing appropriate measures for mitigating the Cry resistance and improving current resistance management programs to sustain $H$. zea susceptibility to Vip3A.

\section{Results}

2.1. Resistance to Cry1Ab in Helicoverpa zea is Common Across the Southeastern United States

Cry1 $\mathrm{Ab}$ susceptibility of $\mathrm{F}_{1}$ or $\mathrm{F}_{2}$ neonates of 30 field populations collected during 2018 (20 populations) and 2019 (10) was compared with that of a known Bt-susceptible laboratory strain (BZ) using diet-overlay bioassays. These field insect populations were collected from non-Bt corn (18 populations), Cry corn (11), and Cry/Vip3A cotton (1) fields (Figure 1; Table 1). The bioassays confirmed that BZ was susceptible to Cry1Ab with a median lethal concentration $\left(\mathrm{LC}_{50}\right)$ of $0.21 \mu \mathrm{g} / \mathrm{cm}^{2}$ and a $95 \%$ confidence interval $(\mathrm{CI})$ of 0.15 to 0.29 (Table 1 ).

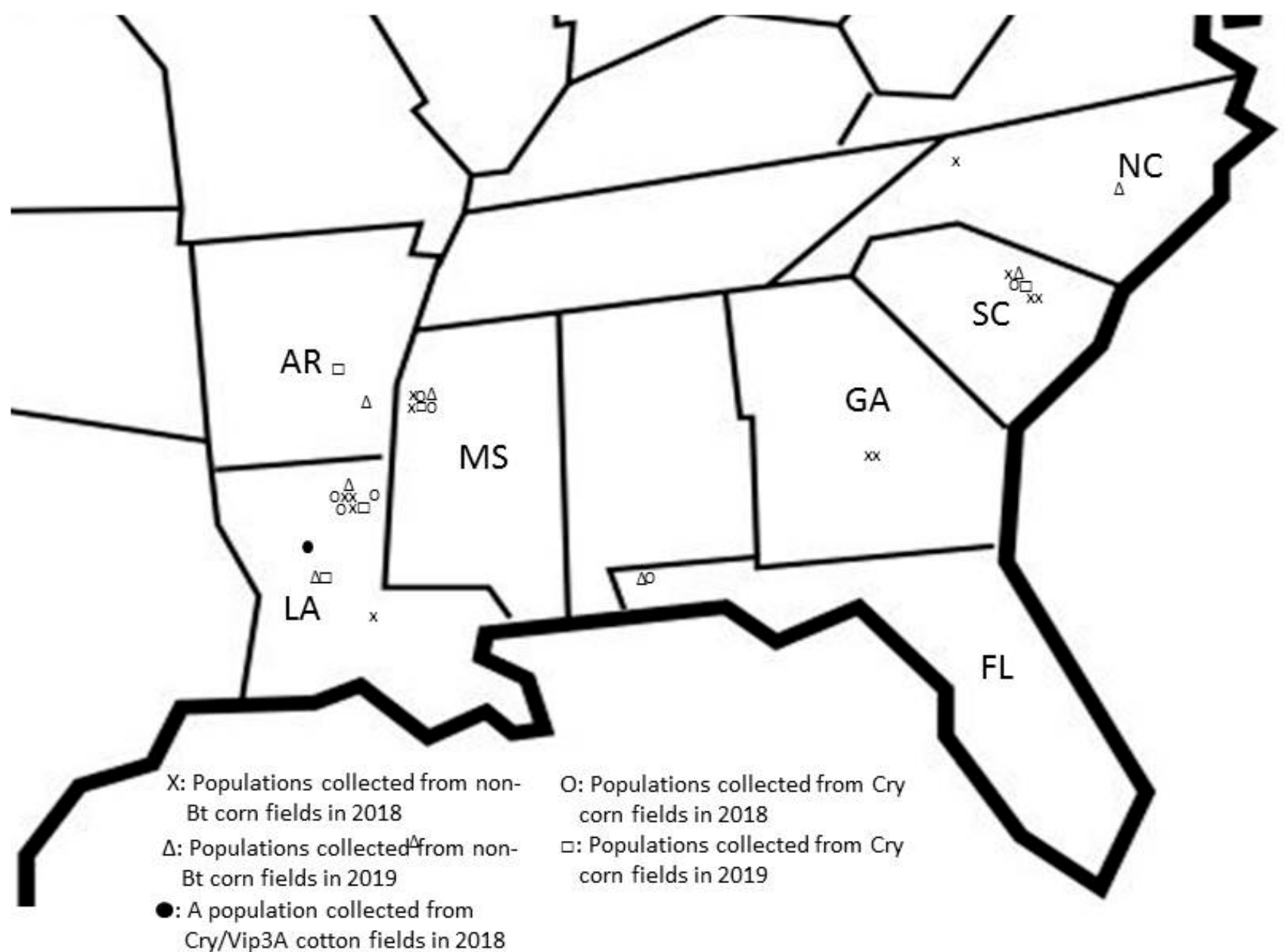

Figure 1. Collection sites of Helicoverpa zea populations in seven states of the southeastern U. S. during 2018 and 2019. 
Table 1. Susceptibility of Helicoverpa zea populations collected from seven southeastern states of the U.S. to Cry1Ab toxin.

\begin{tabular}{|c|c|c|c|c|c|c|c|c|c|}
\hline $\begin{array}{c}\text { Insect } \\
\text { Populations }^{\mathrm{a}}\end{array}$ & $\begin{array}{l}\text { Collection Locations: } \\
\text { County/Parish, State }\end{array}$ & Host Sources ${ }^{c}$ & $\begin{array}{l}\text { No. Larvae } \\
\text { Assayed }\end{array}$ & Slope \pm SE & $\begin{array}{c}\mathrm{LC}_{50}(95 \% \mathrm{CI})^{\mathrm{d}} \\
\left(\mu \mathrm{g} / \mathrm{cm}^{2}\right)\end{array}$ & $x^{2}$ & $p$-Value & $\underset{\text { ratio }^{\mathrm{e}}}{\text { Resistance }}$ & $\begin{array}{c}\% \text { Larval Survivorship } \\
\text { at } 10 \mu \mathrm{g} / \mathrm{cm}^{2}\end{array}$ \\
\hline $\mathrm{BZ}$ & Benzon Research Inc. & Laboratory & 1699 & $1.29 \pm 0.12$ & $0.21(0.15,0.29)$ & 304.09 & $<0.0001$ & $\mathrm{n} / \mathrm{a}$ & $0.0 \pm 0.0$ \\
\hline & & & \multicolumn{7}{|c|}{ Insect populations collected during 2018} \\
\hline LA-BR-NBt & East Baton Rouge, LA & Non-Bt corn & 324 & $1.30 \pm 0.28$ & $3.51(2.36,5.78)$ & 9.20 & 0.5128 & 17 & $26.7 \pm 3.7$ \\
\hline LA-WB-NBt-1 & Franklin, LA & Non-Bt corn & 983 & $0.99 \pm 0.18$ & $9.10(4.78,29.8)$ & 57.30 & $<0.0001$ & 43 & $50.8 \pm 8.1$ \\
\hline LA-WB-NBt-2 & Franklin, LA & Non-Bt corn & 368 & $1.85 \pm 0.32$ & $9.10(6.74,14.56)$ & 13.00 & 0.2239 & 43 & $50.2 \pm 3.1$ \\
\hline LA-WB-NBt-3 & Franklin, LA & Non-Bt corn & 414 & $1.48 \pm 0.30$ & $7.71(5.30,10.5)$ & 9.23 & 0.5106 & 37 & $18.6 \pm 1.7$ \\
\hline LA-WB-VT2P-1 & Franklin, LA & VT-2P corn & 419 & $0.93 \pm 0.20$ & $14.4(7.4,49.0)$ & 36.18 & 0.0043 & 69 & $56.7 \pm 4.3$ \\
\hline LA-SI-VT2P & Tensas, LA & VT-2P corn & 394 & $2.81 \pm 0.35$ & $12.4(10.0,15.3)$ & 15.57 & 0.1126 & 59 & $55.9 \pm 5.7$ \\
\hline LA-WB-SMT & Franklin, LA & SmartStax corn & 255 & $\mathrm{n} / \mathrm{a}$ & $>31.6$ & $\mathrm{n} / \mathrm{a}$ & $\mathrm{n} / \mathrm{a}$ & $>150$ & $73.0 \pm 4.1$ \\
\hline LA-GT-WS3 & Grant, LA & WideStrike- 3 cotton & 485 & $\mathrm{n} / \mathrm{a}$ & $>10$ & $\mathrm{n} / \mathrm{a}$ & $\mathrm{n} / \mathrm{a}$ & $>48$ & $51.8 \pm 1.0$ \\
\hline MS-ST-NBt-1 & Washington, MS & Non-Bt corn & 374 & $0.94 \pm 0.12$ & $1.84(1.27,2.82)$ & 25.73 & 0.1062 & 9 & $24.2 \pm 4.8$ \\
\hline MS-LL-NBt & Washington, MS & Non-Bt corn & 360 & $0.78 \pm 0.14$ & $2.77(1.50,6.88)$ & 28.59 & 0.0536 & 13 & $24.7 \pm 5.8$ \\
\hline MS-ST-VT2P-1 & Washington, MS & VT-2P corn & 371 & $\mathrm{n} / \mathrm{a}$ & $>10$ & $\mathrm{n} / \mathrm{a}$ & $\mathrm{n} / \mathrm{a}$ & $>48$ & $54.7 \pm 6.9$ \\
\hline MS-LL-Intra & Washington, MS & Intrasect corn & 287 & $0.82 \pm 0.24$ & $10.75(5.76,64.5)$ & 15.17 & 0.1261 & 51 & $51.8 \pm 10.6$ \\
\hline GA-TF-NBt-1 & Tift, GA & Non-Bt corn & 228 & $\mathrm{n} / \mathrm{a}$ & $>10$ & $\mathrm{n} / \mathrm{a}$ & $\mathrm{n} / \mathrm{a}$ & $>48$ & $74.4 \pm 10.2$ \\
\hline GA-TF-NBt-2 & Tift, GA & Non-Bt corn & 439 & $\mathrm{n} / \mathrm{a}$ & $>10$ & $\mathrm{n} / \mathrm{a}$ & $\mathrm{n} / \mathrm{a}$ & $>48$ & $73.5 \pm 6.5$ \\
\hline SC-FR-NBt-1 & Florence, SC & Non-Bt corn & 362 & $\mathrm{n} / \mathrm{a}$ & $>10$ & $\mathrm{n} / \mathrm{a}$ & $\mathrm{n} / \mathrm{a}$ & $>48$ & $66.9 \pm 7.6$ \\
\hline SC-FR-NBt-2 & Florence, SC & Non-Bt corn & 342 & $\mathrm{n} / \mathrm{a}$ & $>10$ & $\mathrm{n} / \mathrm{a}$ & $\mathrm{n} / \mathrm{a}$ & $>48$ & $82.9 \pm 1.6$ \\
\hline SC-DL-NBt-1 & Darlington, SC & Non-Bt corn & 384 & $\mathrm{n} / \mathrm{a}$ & $>10$ & $\mathrm{n} / \mathrm{a}$ & $\mathrm{n} / \mathrm{a}$ & $>48$ & $59.4 \pm 11.0$ \\
\hline SC-DL-VT2P-1 & Darlington, SC & VT-2P corn & 341 & $0.67 \pm 0.19$ & $4.61(1.84,38.1)$ & 45.00 & 0.0004 & 22 & $44.1 \pm 15.6$ \\
\hline FL-SR-VT2P & \multicolumn{9}{|c|}{ Insect populations collected during 2019} \\
\hline LA-WB-NBt-4 & Franklin, LA & Non-Bt corn & 437 & $\mathrm{n} / \mathrm{a}$ & $>10$ & $\mathrm{n} / \mathrm{a}$ & $\mathrm{n} / \mathrm{a}$ & $>48$ & $68.7 \pm 6.8$ \\
\hline LA-AX-NBt & Rapides, LA & Non-Bt corn & 441 & $\mathrm{n} / \mathrm{a}$ & $>10$ & $\mathrm{n} / \mathrm{a}$ & $\mathrm{n} / \mathrm{a}$ & $>48$ & $79.4 \pm 6.1$ \\
\hline LA-WB-VT2P-2 & Franklin, LA & VT-2P corn & 478 & $\mathrm{n} / \mathrm{a}$ & $>10$ & $\mathrm{n} / \mathrm{a}$ & $\mathrm{n} / \mathrm{a}$ & $>48$ & $80.6 \pm 5.6$ \\
\hline LA-AX-VT2P & Rapides, LA & VT-2P corn & 474 & $0.79 \pm 0.11$ & $1.00(0.60,1.77)$ & 31.79 & 0.0810 & 5 & $27.0 \pm 1.6$ \\
\hline MS-ST-NBt-2 & Tensas, LA & Non-Bt corn & 512 & $1.02 \pm 0.16$ & $1.03(0.56,2.09)$ & 84.87 & $<0.0001$ & 5 & $14.6 \pm 4.0$ \\
\hline MS-ST-VT2P-2 & Tensas, LA & VT-2P corn & 447 & $0.75 \pm 0.11$ & $2.32(1.48,4.11)$ & 24.70 & 0.1334 & 11 & $37.9 \pm 8.2$ \\
\hline AR-TR-NBt & Desha, AR & Non-Bt corn & 510 & $0.83 \pm 0.09$ & $0.46(0.31,0.68)$ & 19.87 & 0.5913 & 2 & $9.7 \pm 1.9$ \\
\hline SC-DL-VT2P-2 & Darlington, SC & VT-2P corn & 511 & $0.65 \pm 0.11$ & $5.99(3.24,16.54)$ & 21.74 & 0.2438 & 29 & $34.9 \pm 6.6$ \\
\hline NC-HA-NBt & Harnett, NC & Non-Bt corn & 506 & $1.10 \pm 0.18$ & $8.36(5.43,16.59)$ & 13.36 & 0.4981 & 40 & $50.8 \pm 9.3$ \\
\hline FL-SR-NBt & Jay, FL & Non-Bt corn & 502 & $1.15 \pm 0.25$ & $0.40(0.19,0.72)$ & 33.50 & 0.0024 & 2 & $3.9 \pm 3.9$ \\
\hline
\end{tabular}

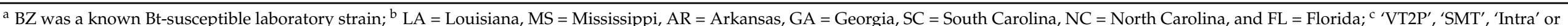

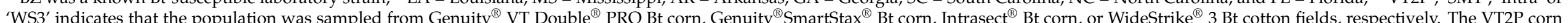

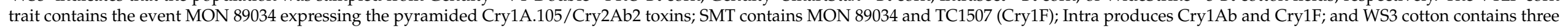

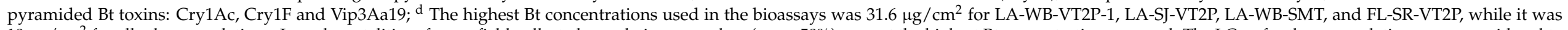

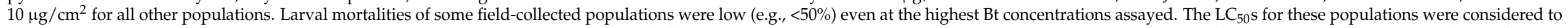

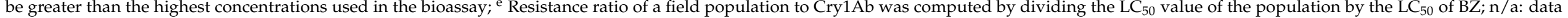
not available. 
LC $_{50}$ values of the 20 populations collected during 2018, which consisted of 12 populations from non-Bt and 8 from Bt crop fields, ranged from 1.84 to $>31.6 \mu \mathrm{g} / \mathrm{cm}^{2}$ (Table 1). Compared to the $\mathrm{LC}_{50}$ value of the reference strain BZ, even the two populations (MS-ST-NBt-1 and FL-SR-VT2P) that showed the lowest $\mathrm{LC}_{50}$ values $\left(1.84 \mu \mathrm{g} / \mathrm{cm}^{2}\right)$ had a resistance ratio of 9-fold to Cry1Ab, and the 9-fold difference was significant based on the non-overlapped 95\% CIs with that of BZ. Five populations had resistance ratios of 13- to 37-fold; the remaining 13 populations had $\geq 43$-fold resistance (Table 1 ). At $10 \mu \mathrm{g} / \mathrm{cm}^{2}, 10$ of the 20 populations collected in 2018 exhibited $>50 \%$ larval survival rates (Table 1 ). The average larval survivorship at $10 \mu \mathrm{g} / \mathrm{cm}^{2}$ was not significantly different between the group of the 12 populations collected from nonBt crops $(49.74 \% \pm 6.4$, mean \pm SEM) and the group of the 7 populations from Bt crops $\left(55.4 \pm 3.3 \%\right.$ ) (Table 2 ) (Note, the survival data at $10 \mu \mathrm{g} / \mathrm{cm}^{2}$ for the population FL-SR-VT2P was not available).

Table 2. Comparisons of the mean survivorships at $10 \mu \mathrm{g} / \mathrm{cm}^{2}$ of Cry1Ab between the two groups of Helicoverpa zea populations collected from non-Bt and Bt crop fields, and between the two groups of populations sampled during 2018 and 2019.

\begin{tabular}{|c|c|c|}
\hline Insect Population Groups & Mean Survivorship \pm SEM $\%$ & $t$-Tests \\
\hline 12 populations collected from non-Bt fields in 2018 & $49.7 \pm 6.4$ & \\
\hline 7 populations collected from Bt fields in 2018 & $55.4 \pm 3.3$ & $t_{17}=-0.64, p=0.5284$ \\
\hline 6 populations collected from non-Bt fields in 2019 & $37.9 \pm 13.3$ & \\
\hline 4 populations collected from Bt fields in 2019 & $45.1 \pm 12.1$ & $t_{8}=-0.38, p=0.7155$ \\
\hline 19 populations collected from non-Bt and Bt fields in 2018 & $51.8 \pm 4.2$ & \\
\hline 10 populations collected from non-Bt and Bt fields in 2019 & $40.8 \pm 8.9$ & $t_{27}=1.28, p=0.2125$ \\
\hline 18 populations collected from non-Bt fields in 2018 and 2019 & $45.8 \pm 6.1$ & \\
\hline 11 populations collected from Bt fields in 2018 and 2019 & $51.7 \pm 4.7$ & $t_{27}=-0.68, p=0.5006$ \\
\hline
\end{tabular}

Cry1Ab LC 50 values for the 10 populations collected during 2019, which included 6 populations from non-Bt and 4 populations from Bt corn fields, ranged from 0.40 to $>10 \mu \mathrm{g} / \mathrm{cm}^{2}$ (Table 1). Compared to the susceptibility of BZ, the $\mathrm{LC}_{50}$ values of the 10 populations equated to resistance ratios of $2-$ to $>48$-fold. The $\mathrm{LC}_{50}$ values of the two populations (AR-TR-NBt and FL-SR-NBt) that showed the lowest resistant ratio (2-fold) were not significantly different from the $\mathrm{LC}_{50}$ of BZ based on the overlapped $95 \%$ CIs with that of BZ. Two populations (LAAX-VT2P and MS-ST-NBt-2) also showed a low level (5-fold) of resistance to Cry1Ab, but the 5 -fold difference was significant based on the non-overlapped 95\% CIs with that of BZ. Another two populations (MS-ST-VT2P-2 and SC-DL-VT2P-2) had resistance ratios of 11- and 29-fold, respectively. Resistance ratios for the remaining four populations were $\geq 40$-fold. At $10 \mu \mathrm{g} / \mathrm{cm}^{2}$, the group of the six populations from non-Bt corn had a mean survival rate of $37.9 \pm 13.3 \%$, which was not significantly different compared to the mean $(45.1 \pm 12.1 \%)$ of the group of the four populations from Bt corn fields (Table 2).

Student's t-tests also showed that the mean survivorship $(40.8 \pm 8.9 \%)$ of the group of the 10 populations collected during 2019 was not significantly different compared to that $(51.8 \pm 4.2 \%)$ of the group of the 19 populations collected during 2018 (Table 2$)$. In addition, mean survivorship $(45.8 \pm 6.1 \%)$ at $10 \mu \mathrm{g} / \mathrm{cm}^{2}$ for the group of the 18 populations collected from non-Bt crops during the two years was also not significantly different from that $(51.7 \pm 4.7 \%)$ of the group of the 11 populations from Bt crop (Table 2).

\subsection{Field Populations of Helicoverpa zea in the Southeastern United States Are Still Susceptible to Vip 3 Aa20}

Vip3Aa20 susceptibility of $\mathrm{F}_{1}$ or $\mathrm{F}_{2}$ neonates of 29 field populations of $H$. zea collected during 2018 (18 populations) and 2019 (11), along with BZ, was assayed using the diet-overlay bioassays (Figure 1; Table 3). These field populations were collected from non-Bt corn (18 populations), Cry corn (10), and Cry/Vip3A cotton (1) fields. Twenty-seven of the 29 populations were also assayed against $\mathrm{Cry} 1 \mathrm{Ab}$ (mentioned above). Probit analysis estimated the $\mathrm{LC}_{50}$ of BZ to be $0.40 \mu \mathrm{g}$ Vip3Aa20/ $\mathrm{cm}^{2}$ with a $95 \%$ CI of 0.30 to 0.51 (Table 3 ). 
Table 3. Susceptibility of Helicoverpa zea populations collected from seven southeastern states of the U.S. to Vip3Aa20 toxin.

\begin{tabular}{|c|c|c|c|c|c|c|c|c|}
\hline Insect Populations ${ }^{a}$ & $\begin{array}{l}\text { Collection Locations: } \\
\text { County/Parish, State }\end{array}$ & Host Sources $^{c}$ & $\begin{array}{l}\text { No. Larvae } \\
\text { Assayed }\end{array}$ & Slope \pm SE & $\begin{array}{c}\mathrm{LC}_{50}(95 \% \mathrm{CI}) \\
\left(\mu \mathrm{g} / \mathrm{cm}^{2}\right)\end{array}$ & $x^{2}$ & $p$-Value & $\begin{array}{c}\text { Susceptibility } \\
\text { Ratio }^{d}\end{array}$ \\
\hline \multirow{2}{*}{\multicolumn{9}{|c|}{$\begin{array}{c}\text { Laboratory } \quad 1652 \\
\text { Insect populations collected during } 2018\end{array}$}} \\
\hline & & & & & & & & \\
\hline LA-DR-NDt & East Eanklin & 1 von-Dicom & 1004 & $4.41 \pm 0.60$ & $0.20(0.17,0.23)$ & 12.49 & 0.2535 & -2.0 \\
\hline LA-WB-NBt-2 & Franklin, LA & Non-Bt corn & 1004 & $2.43 \pm 0.24$ & $0.96(0.78,1.12)$ & 23.68 & 0.0501 & 2.4 \\
\hline LA-WR_NBt-3 & Franklin, LA & Non-Bt corn & 383 & $2.14 \pm 0.54$ & $0.13(0.06,0.22)$ & 50.73 & $<0.0001$ & -3.1 \\
\hline $\begin{array}{l}\text { LA-VWD-NDD-3 } \\
\text { LA-WB-SMT }\end{array}$ & Franklin, LA & Non-Bt corn & 367 & $1.92 \pm 0.23$ & $0.21(0.16,0.27)$ & 9.85 & 0.7730 & -1.9 \\
\hline & & SmartStax corn & 350 & $2.19 \pm 0.23$ & $0.37(0.26,0.41)$ & 14.19 & 0.7163 & -1.1 \\
\hline LA-GT-WS3 & Grant, LA & $\begin{array}{l}\text { 1deStrike } \\
\text { cotton }\end{array}$ & 370 & $1.71 \pm 0.25$ & $0.92(0.59,1.31)$ & 22.11 & 0.0763 & 2.3 \\
\hline MS-ST-NBt-1 & Washington, MS & Non-Bt corn & 362 & $1.43 \pm 0.24$ & $0.32(0.17,0.51)$ & 43.94 & 0.0006 & -1.3 \\
\hline MS-LL-NBt & Washington, MS & Non-Bt corn & 343 & $1.89 \pm 0.47$ & $0.14(0.05,0.23)$ & 45.11 & $<0.0001$ & -2.9 \\
\hline MS-ST-VT2P-1 & Washington, MS & VT-2P corn & 375 & $3.16 \pm 0.48$ & $0.48(0.36,0.65)$ & 30.40 & 0.0067 & 1.2 \\
\hline MS-LL-Intra & Washington, MS & Intrasect corn & 358 & $1.96 \pm 0.26$ & $0.46(0.32,0.66)$ & 32.91 & 0.0116 & 1.2 \\
\hline GA-TF-NBt-1 & Tift, GA & Non-Bt corn & 369 & $2.34 \pm 0.26$ & $0.42(0.34,0.51)$ & 10.86 & 0.9003 & 1.1 \\
\hline GA-TF-NBt-2 & Tift, GA & Non-Bt corn & 446 & $\mathrm{n} / \mathrm{a}$ & $<0.0316$ & $\mathrm{n} / \mathrm{a}$ & $\mathrm{n} / \mathrm{a}$ & $<-11.5$ \\
\hline SC-FR-NBt-1 & Florence, SC & Non-Bt corn & 368 & $2.55 \pm 0.41$ & $0.30(0.21,0.41)$ & 35.75 & 0.0049 & -1.3 \\
\hline SC-FR-NBt-2 & Florence, SC & Non-Bt corn & 365 & $2.22 \pm 0.24$ & $0.34(0.27,0.42)$ & 11.61 & 0.6379 & -1.2 \\
\hline SC-DL-NBt-1 & Darlington, SC & Non-Bt corn & 438 & $4.91 \pm 0.59$ & $0.88(0.78,1.01)$ & 4.90 & 0.9872 & 2.2 \\
\hline SC-DL-VT2P-1 & Darlington, SC & VT-2P corn & 367 & $2.05 \pm 0.33$ & $0.31(0.21,0.45)$ & 29.69 & 0.0084 & -1.3 \\
\hline NC-CD-NBt & Caldwell, NC & Non-Bt corn & 369 & $1.79 \pm 0.17$ & $0.48(0.37,0.61)$ & 23.69 & 0.1656 & 1.2 \\
\hline LA-WB-NBt-4 & Franklin, LA & Non-Bt corn & 511 & $2.27 \pm 0.21$ & $0.25(0.20,0.30)$ & 14.66 & 0.6853 & -1.6 \\
\hline LA-AX-NBt & Rapides, LA & Non-Bt corn & 497 & $2.57 \pm 0.26$ & $1.34(1.10,1.63)$ & 17.79 & 0.2165 & 3.4 \\
\hline LA-WB-VT2P-2 & Franklin, LA & VT-2P corn & 256 & - & $<0.316$ & - & - & $<1.3$ \\
\hline LA-AX-VT2P & Rapides, LA & VT-2P corn & 512 & $2.98 \pm 0.30$ & $0.06(0.05,0.07)$ & 24.04 & 0.1539 & -6.7 \\
\hline MS-ST-VT2P-2 & Washington, MS & VT-2P corn & 512 & $1.49 \pm 0.14$ & $0.21(0.16,0.28)$ & 21.70 & 0.2455 & -1.9 \\
\hline AR-TR-NBt & Desha, AR & Non-Bt corn & 500 & $1.21 \pm 0.18$ & $0.04(0.02,0.06)$ & 33.71 & 0.0137 & -10.0 \\
\hline AR-LK-VT2P & Lonoke, AR & VT-2P corn & 507 & $1.86 \pm 0.21$ & $3.60(2.84,4.69)$ & 6.51 & 0.9520 & 9.0 \\
\hline SC-DL-NBt-2 & Darlington, SC & Non-Bt corn & 1015 & $1.95 \pm 0.19$ & $1.32(1.03,1.71)$ & 93.73 & $<0.0001$ & 3.3 \\
\hline SC-DL-VT2P-2 & Darlington, SC & VT-2P corn & 511 & $1.25 \pm 0.13$ & $0.65(0.49,0.96)$ & 15.31 & 0.6409 & 1.6 \\
\hline NC-HA-NBt & Harnett, NC & Non-Bt corn & 511 & $3.07 \pm 0.33$ & $0.08(0.06,0.09)$ & 18.20 & 0.1977 & -5.0 \\
\hline FL-SR-NBt & Jay, FL & Non-Bt corn & 509 & $1.37 \pm 0.14$ & $0.12(0.09 .0 .17)$ & 41.34 & 0.0287 & -3.3 \\
\hline
\end{tabular}

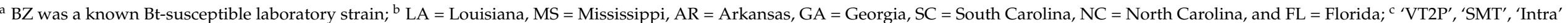

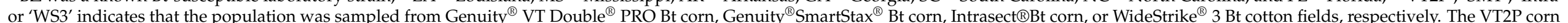

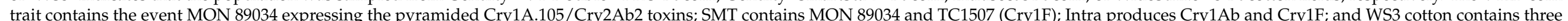

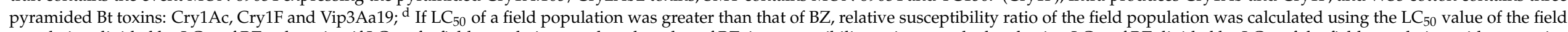

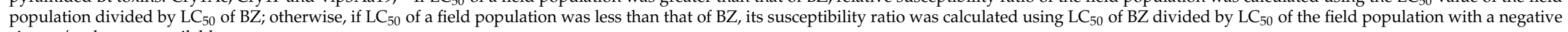
sign; $\mathrm{n} / \mathrm{a}$ : data not available. 
Compared to BZ, among the 18 field populations collected during 2018, which consisted of 12 populations from non-Bt and 6 from Bt corn fields, 10 populations had similar LC $_{50}$ values as BZ based on their overlapping 95\% CIs with that of BZ; six had significantly lower $\mathrm{LC}_{50}$ values, while two had significantly greater $\mathrm{LC}_{50}$ values (Table 3 ). Among the 18 populations, the most susceptible population (GA-TF-NBt-2) to Vip3Aa20 was >11.5-fold more sensitive than BZ. Susceptibility ratios relative to BZ of all other field populations, ranged from 3.1-fold more sensitive to 2.4-fold more tolerant (Table 3). Relative to BZ, the only population (LA-GT-WS3) collected from cotton plants containing Vip3Aa19 gene showed a 2.3-fold more tolerant to the Vip3Aa20 protein. The 2.3-fold difference was significant based on the non-overlapped $95 \%$ CIs of the $\mathrm{LC}_{50}$ s with that of $\mathrm{BZ}$, but the susceptibility of LA-GT-WS3 was well within the range of other field populations (Table 3). Probit analysis on the pooled bioassay data of the 12 populations collected from non-Bt corn showed an $\mathrm{LC}_{99}$ of $7.0 \mu \mathrm{g} / \mathrm{cm}^{2}$ with a $95 \%$ CI of 5.0 to 10.7 . Student's $t$-tests showed that the mean $\mathrm{LC}_{50}$ value $\left(0.37 \pm 0.08 \mu \mathrm{g} / \mathrm{cm}^{2}\right)$ of the group of the 12 populations from non-Bt plants was similar to that $\left(0.45 \pm 0.10 \mu \mathrm{g} / \mathrm{cm}^{2}\right)$ of the group of the 6 populations from Bt plants (Table 4).

Table 4. Comparisons of the mean $\mathrm{LC}_{50}$ values of Vip3Aa20 between the two groups of Helicoverpa zea populations collected from non-Bt and Bt crop fields, and between the two groups of populations sampled during 2018 and 2019.

\begin{tabular}{|c|c|c|}
\hline Insect Population Groups & $\begin{array}{c}\text { Mean } \mathrm{LC}_{50} \pm \text { SEM } \\
\left(\mu \mathrm{g} / \mathrm{cm}^{2}\right)\end{array}$ & $t$-Tests \\
\hline 12 populations collected from non-Bt fields in 2018 & $0.37 \pm 0.08$ & \\
\hline 6 populations collected from Bt fields in 2018 & $0.45 \pm 0.10$ & $t_{17}=-0.60, p=0.5540$ \\
\hline 6 populations collected from non-Bt fields in 2019 & $0.53 \pm 0.26$ & \\
\hline 5 populations collected from Bt fields in 2019 & $0.97 \pm 0.67$ & $t_{8}=-0.67, p=0.5221$ \\
\hline 18 populations collected from non-Bt and Bt fields in 2018 & $0.42 \pm 0.06$ & \\
\hline 11 populations collected from non-Bt and Bt fields in 2019 & $0.73 \pm 0.32$ & $t_{27}=-1.26, p=0.2175$ \\
\hline 18 populations collected from non-Bt fields in 2018 and 2019 & $0.42 \pm 0.10$ & \\
\hline 11 populations collected from Bt fields in 2018 and 2019 & $0.69 \pm 0.30$ & $t_{27}=-1.01, p=0.3234$ \\
\hline
\end{tabular}

Among the 11 populations collected during 2019, which included 6 from non-Bt and 5 from Bt corn fields, three had similar $\mathrm{LC}_{50}$ values as BZ; five had significantly lower $\mathrm{LC}_{50}$ values; and three had significantly greater $\mathrm{LC}_{50}$ values than $\mathrm{BZ}$ (Table 3 ). The susceptibility ratios of these 11 populations, relative to $\mathrm{BZ}$, ranged from 10.0-fold more sensitive to 9.0-fold more tolerant (Table 3). Student's $t$-tests showed that the mean $\mathrm{LC}_{50}$ value $\left(0.53 \pm 0.26 \mu \mathrm{g} / \mathrm{cm}^{2}\right)$ of the group of the six populations from non-Bt plants was not significantly different to that $\left(0.97 \pm 0.67 \mu \mathrm{g} / \mathrm{cm}^{2}\right)$ of the group of the five populations from Bt plants (Table 4).

In addition, t-tests also showed that the mean $\mathrm{LC}_{50}$ value $\left(0.73 \pm 0.32 \mu \mathrm{g} / \mathrm{cm}^{2}\right)$ of the group of the 11 populations collected during 2019 was not significantly different from that $\left(0.40 \pm 0.06 \mu \mathrm{g} / \mathrm{cm}^{2}\right)$ of the group of the 18 populations collected during 2018 (Table 4 ). Furthermore, the mean $\mathrm{LC}_{50}$ value $\left(0.42 \pm 0.10 \mu \mathrm{g} / \mathrm{cm}^{2}\right)$ of the group of the 18 populations collected from non-Bt crops during the two years was also not significantly different from that $\left(0.69 \pm 0.30 \mu \mathrm{g} / \mathrm{cm}^{2}\right)$ of the group of the 11 populations from Bt crop fields (Table 4$)$.

\subsection{There Are No Significant Relationships Between the Susceptibilities of Helicoverpa Zea Populations to Cry1Ab and Vip3Aa20 Proteins}

Seventeen populations collected during 2018 and nine populations sampled during 2019 were assayed against both Cry1Ab and Vip3Aa20 in the study. Linear regression analysis showed that the larval survivorships $(\mathrm{X})$ at $10 \mu \mathrm{g}$ Cry1 Ab/ $\mathrm{cm}^{2}$ were not significantly correlated to the $\mathrm{LC}_{50}$ values $(\mathrm{Y})$ of Vip3Aa20 for the 17 populations collected in $2018\left(\mathrm{Y}=0.296+0.002 \mathrm{X} ; R^{2}=0.024 ; p=0.5524\right)$ and for the 9 populations collected in 2019 $\left(\mathrm{Y}=0.045+0.008 \mathrm{X} ; R^{2}=0.218 ; p=0.2051\right)$, as well as for the full set of the 26 populations collected across both years $\left(Y=0.156+0.005 X ; R^{2}=0.1086 ; p=0.1003\right)$. 


\section{Discussion}

Transgenic corn and cotton containing single Cry1 genes (e.g., Cry1Ac or Cry1 Ab) were first commercialized in the U.S. in 1995/1996 [4]. The single-gene Cry1 Ab corn hybrids did not provide a high dose against $H$. zea, but they were originally able to suppress the pest population and reduce ear damage $[10,11]$. Two studies reported that field populations of $H$. zea were relatively susceptible to Cry $1 \mathrm{Ab}$ in the U.S. during the early commercial use of Cry1A crops [33,34]. The current study showed that, although considerable variations still existed among the populations evaluated, the majority of $H$. zea populations exhibited significant levels of resistance to $\mathrm{Cry} 1 \mathrm{Ab}$, and the overall resistance levels were consistent between the two groups of populations collected from non-Bt and Bt plants, as well as between the two groups of populations collected during 2018 and 2019. In particular, for the seven populations collected from North and South Carolina, the three least resistant populations exhibited 17- to 40-fold resistance to Cry1 Ab, and the other four had resistance ratios of $>48$-fold. The results of the current study validated that the previous observations in the field showing a lack of significant impact of Cry1 Ab corn on kernel injury and H. zea occurrence was due to resistance development in the insect [12]. The results of the current study further demonstrate that the resistance to Cry1 Ab corn in $\mathrm{H}$. zea has become widely distributed across the southeastern U.S.

Ali and Luttrell [20] evaluated Vip3Aa19 susceptibility of $31 \mathrm{H}$. zea populations collected during 2004 to 2007 from the southern U.S.; susceptibility ratios relative to a laboratory strain ranged from 27 -fold more susceptible to 2.2 -fold more tolerant. The current study showed that the overall Vip3Aa20 susceptibility of $H$. zea populations collected during 2018 and 2019 was similar as that reported in the reference [20]. In addition, the regression analysis exhibited that there were no significant relationships between the Cry1Ab resistance levels and Vip3Aa20 susceptibilities for the populations collected in the current study. The results show that the Cry1Ab-resistant $\mathrm{H}$. zea populations do not present cross-resistance to Vip3Aa20; and the populations in the region, regardless of their host plant sources (non-Bt and Bt crops), collection years (2018 and 2019), or their resistance levels to Cry1 Ab, are still susceptible to the Vip3Aa20 toxin. An early study also showed that a Cry1Ac-selected H. zea population was not cross-resistant to Vip3A toxin [35], while another study reported that a Cry1Ac-selected $H$. zea strain was 1.6-fold less susceptible to Vip3A than the un-selected counterpart [36]. A recent review based on bioassays with several insect species targeted by Bt corps showed a weak cross-resistance pattern between Cry1 and Vip3 [37].

Based on the $95 \%$ CI of LC 99 estimated from the pooled bioassay data with the 12 populations collected from non-Bt corn during 2018, we believe that Vip3Aa20 concentrations between 5 to $10 \mu \mathrm{g} / \mathrm{cm}^{2}$ may be used as diagnostic concentrations for monitoring Vip3A susceptibility in future. However, additional studies are warranted to identify more specific concentrations for the resistance monitoring. The use of only the 12 populations collected from non-Bt corn during 2018 for estimation of the diagnostic concentrations should minimize any possible effect of recent field selections with Vip3A on the $H$. zea populations. As mentioned above, until recently the use of Vip3A in both transgenic corn and cotton in the U.S. had been very rare. In Brazil, a concentration of $6.4 \mu \mathrm{g} V i p 3 \mathrm{Aa} 20 / \mathrm{cm}^{2}$ has been recommended as a diagnostic concentration for Vip3A susceptibility monitoring in H. zea [31], which is within the range of the concentrations suggested in the current study.

The second generation Bt crops containing pyramided Cry1/Cry2 genes (e.g., Cry1Ac/ Cry2Ab for cotton and Cry1A.105/Cry2Ab for corn) became available in 2002 (Bt cotton) and 2010 (Bt corn). These pyramided Cry crop traits initially were effective against H. zea [38-40]. A few years after their use, unexpected H. zea survival and plant damage were frequently observed in the U.S. [1,6-9]. These unexpected control problems have been documented to be a result of resistance development to Cry1/Cry2 [7-9]. Recent studies have shown that the Cry1/Cry2 resistance in H. zea has become widely distributed in the southern U.S. [8,9,41,42]. As reported in the reference [26], in the current global Bt crop market, there are only three groups of Bt toxins with different modes of action targeting 
lepidopteran pests. These are Cry1 (Cry1Ac in cotton, Cry1A.105 in corn, and Cry1Ab and Cry1F in both cotton and corn), Cry2 (Cry2Ae in cotton and Cry2Ab in both cotton and corn), and Vip3A (Vip3Aa19 in cotton and Vip3Aa20 in corn). To date, transgenic corn and cotton traits expressing Vip3A have been effective against $H$. zea, and no field resistance has been documented $[21,22,24,43,44]$. In the current study, we also conducted massive field surveys ( $>10,000$ ears) for $H$. zea larval survival on corn plants containing Vip3Aa20 gene at multiple locations in Louisiana. The surveys found only a few small live larvae (3rd instars) of $H$. zea. The results of the field surveys also showed no sign of resistance development in the insect to the Vip3Aa20 corn. On the other hand, cross-resistance among Cry1 or Cry2 toxins in lepidopteran species has been well-documented [16,26,45-47]. Because of cross-resistance, resistance to one Cry1 or Cry2 toxin will likely result in resistance to all other Cry1 or Cry2 toxins in the plants. Therefore, the widespread Cry1/Cry2 resistance makes Vip3A the only fully active Bt toxin expressed in transgenic plants for controlling H. zea. In addition, unexpected control problems with transgenic corn and cotton containing the Vip3A gene have already been reported in the U.S. [1,9]. Therefore, preservation of H. zea susceptibility to Vip3A is essential for the continued success of Bt crop technology, especially for the cotton industry in the U.S. where H. zea is a key economic pest [1]. Further studies are necessary to understand the impact of the selection with Bt corn on the resistance evolution in H. zea to Vip3A cotton in the U.S.

\section{Conclusions}

Resistance to Cry1 Ab in $\mathrm{H}$. zea is widely distributed in southeastern U.S. Cry1 Abresistant $H$. zea populations showed no cross-resistance to Vip3Aa20 and the insect in the region is still susceptible to the Vip3Aa20 toxin expressed in MIR 162 corn. A concentration range of 5 to $10 \mu \mathrm{g}$ Vip3Aa20 $/ \mathrm{cm}^{2}$ may be used as potential diagnostic concentrations in susceptibility monitoring in future. Implementation of effective measures for mitigating the Cry resistance is critical to sustain H. zea susceptibility to Vip3A. Additional studies are necessary to elucidate the effect of the selection with Bt corn on resistance evolution in H. zea to Vip3A cotton in the U.S.

\section{Materials and Methods}

\subsection{Insect Sources}

During 2018-2019, a total of 32 populations of H. zea were established from collections of 3rd to 6th instar larvae from major corn areas in seven southeastern states of the U.S.: 12 populations from Louisiana (LA), 6 from Mississippi (MS), 2 from Arkansas (AR), 2 from Georgia (GA), 6 from South Carolina (SC), 2 from North Carolina (NC), and 2 from Florida (FL) (Figure 1, Tables 1 and 3). Twenty of the 32 populations were collected during 2018, which consisted of 12 populations from non-Bt corn, 7 from Cry Bt corn, and 1 from WideStrike 3 (Cry/Vip3A) Bt cotton (WS3). The other 12 populations were collected during 2019, which included 7 from non-Bt corn and 5 from Cry corn fields. Among the 12 populations collected from Cry corn during the two years, 10 were collected from Genuity ${ }^{\circledR}$ VT Double Pro ${ }^{\text {TM }}$ corn (VT2P), 1 from Genuity ${ }^{\circledR}$ SmartStax ${ }^{\circledR}$ corn (SMT), and 1 from Optimum ${ }^{\circledR}$ Intrasect $^{\circledR}$ corn (Intra). VT2P corn produces two pyramided Bt toxins: Cry1A.105 and Cry2Ab2; SMT corn expresses three Bt toxins: Cry1A.105, Cry2Ab2, and Cry $1 \mathrm{~F}$ targeting above-ground lepidopteran pests; Intra corn produces both $\mathrm{Cry} 1 \mathrm{Ab}$ and Cry1F; and WS3 cotton expresses Cry1Ac, Cry1F, and Vip3Aa19 [48,49]. Populations collected from a same site used in the study were not necessary from the same spot (fields), but some were from same farms. In addition, massive field surveys ( $>10,000$ ears) for H. zea survival on Vip3Aa20 corn were performed at multiple locations in Louisiana during 2018 and 2019. The original purpose of the field surveys was to establish field-collected H. zea populations from Vip3Aa20 corn fields for laboratory bioassays with Bt proteins. However, the surveys found only a few small larvae ( $3^{\text {rd }}$ instars) and thus, populations from Vip3Aa20 corn were not able to be established in this study. 


\subsection{Insect Rearing}

Each field insect population originated from collections of 52 to 950 third to sixth instar larvae. Field-collected larvae were individually reared in 30-ml cups containing Ward's Heliothis meridic diet (Rochester, NY, USA) as described in the reference [8]. Pupae that developed from field-collected larvae for each population were placed into a 20-L mesh cage (Seville Classics, INC., Torrance, CA, USA) and the cages containing pupae were placed in an insect rearing room at $26{ }^{\circ} \mathrm{C},>70 \%$ R.H. and a photoperiod of 14:10 h (L:D) for adult emergence, mating, and oviposition [8]. Eggs were harvested daily and stored in plastic bags inflated with air. Neonates of the first $\left(\mathrm{F}_{1}\right)$ or second $\left(\mathrm{F}_{2}\right)$ generation of each field-collected population were used in bioassays to determine the susceptibility to Cry1Ab and Vip3Aa20. A laboratory strain of H. zea (BZ) obtained from Benzon Research Inc. (Carlisle, PA, USA) was included in the bioassays as a reference. BZ has been documented to be susceptible to several Bt toxins including Cry1A.105, Cry2Ab2, Cry1Ab, and Vip3Aa20 [8,25,41,42].

\subsection{Diet-Overlay Bioassays}

A diet-overlay bioassay method described in the reference [8] was used to determine the susceptibility of BZ and field-collected populations to Cry1 Ab and Vip3Aa20 toxins. Lyophilized Cry1 Ab (84.3\% purity) and Vip3Aa20 (86.5\% purity) toxins were provided by Syngenta Biotechnology (Research Triangle Park, NC, USA). Three (LA-WB-VT2P-1, LA-SJ-VT2P and MS-ST-NBt-2) of the field-collected populations were assayed against Cry1Ab, but not Vip3Aa20; and two populations (AR-LK-VT2P and SC-DL-NBt-2) were tested against Vip3Aa20, but not Cry1Ab. All other 27 field populations were assayed against both Cry1Ab and Vip3Aa20. During the study, three independent bioassays with BZ were conducted for each of the two Bt toxins: two bioassays in 2018 and one in 2019.

Most bioassays for field populations consisted of six or seven Bt concentrations with a range of 0.0316 to $10.0 \mu \mathrm{g} / \mathrm{cm}^{2}$ (six-concentration assay) or 0.01 to $10.0 \mu \mathrm{g} / \mathrm{cm}^{2}$ (sevenconcentration assay). For the four populations (LA-WB-VT2P-1, LA-SJ-VT2P, LA-WB$\mathrm{SMT}$, and FL-SR-VT2P), the highest concentration used in bioassays with Cry1 Ab was $31.6 \mu \mathrm{g} / \mathrm{cm}^{2}$. The reason for use of a higher Cry1 Ab concentration for these populations was that many populations had exhibited $<50 \%$ mortality at $10 \mu \mathrm{g} / \mathrm{cm}^{2}$ in earlier bioassays. Each bioassay for BZ utilized 7 to 9 concentrations with a range of 0.000656 to $10.0 \mu \mathrm{g} / \mathrm{cm}^{2}$. To obtain the appropriate toxin concentrations for bioassays, Bt solutions were prepared by mixing lyophilized toxins with distilled water containing $0.1 \%$ Triton X-100. Diet treated with distilled water containing $0.1 \%$ Triton X-100 only was included as a control for each bioassay. In the bioassays, approximately $0.8 \mathrm{ml}$ of the Southland liquid diet (Lake Village, AR) was applied into each well of 16- or 32-well plates that were made by cutting each 128-well CD-International tray (Pitman, NJ, USA) into four or eight plates. After the diet solidified, $50 \mu \mathrm{l}$ of an appropriate Bt solution or $0.1 \%$ Triton X-100 distilled water only (control) was applied to the diet surface in each well using Eppendorf Repeater ${ }^{\circledR}$ M4 pipettes (Pipett.com, San Diego, CA, USA). The plates were then hand-shaken to ensure uniform coverage of the Bt toxin onto the diet surface [8]. After the Bt solution dried, one $H$. zea neonate $(<24 \mathrm{~h})$ was gently placed on the diet surface in each well using a soft hair paint-brush. A bioassay for each combination of insect population and Bt concentration or control utilized four replications (plates) with 16 or 32 larvae in each replicate. The bioassay wells were then covered with BACV16 ventilated lids (CD-International, Pitman, NJ, USA). Bioassay plates containing neonates were maintained in incubators at $\sim 50 \%$ R.H., $26^{\circ} \mathrm{C}$, and a 16:8h (L:D) photoperiod. Number of real dead larvae and the living larvae that were severely stunted and still in 1st or 2nd instar were recorded 7 days after infection. A larva was considered really dead if the body did not move after touching it with a soft hair paint-brush. In this study, a measurement of 'practical mortality' was adopted as the response variable, which was calculated as: larval mortality $(\%)=\{[100 \times$ (number of dead larvae + number of living larvae that were severely stunted and still in 1st or 2nd instar after 7 days in the bioassay)] divided by the total number of larvae assayed\} [50]. 
Studies have reported that the criterion of 'practical mortality' is usually more sensitive to measure the responses of insect to Bt toxins than the use of 'real mortality' only, because the measurement of 'practical mortality' considers both factors including the 'real mortality' that is based on 'real dead larvae' and the number of the 'severely stunted larvae' that is based on larval growth inhabitation $[8,50]$.

\subsection{Statistical Analysis}

Larval (practical) mortality of $H$. zea populations for each Bt concentration in each dose-response bioassay was corrected for control mortality [51]. The corrected data were analyzed using probit analysis with a normal distribution model (SAS PROC PROBIT) $[52,53]$ to calculate the $\mathrm{LC}_{50}$ that resulted in $50 \%$ mortality of the population and the associated 95\% CI. Dose-responses of the susceptible control, BZ strain, in the three bioassays were consistent, and, thus, mortality data were pooled across bioassays for probit analysis. As mentioned above, in the bioassays with Cry1Ab, some field populations exhibited low mortalities (e.g., <50\%) across the concentrations assayed, and thus the corresponding $\mathrm{LC}_{50}$ values were not determined with probit analysis. Instead, $\mathrm{LC}_{50}$ values for these populations were estimated to be greater than the highest Cry $1 \mathrm{Ab}$ concentration tested in bioassays (e.g., $10 \mu \mathrm{g} / \mathrm{cm}^{2}$ ). If the $\mathrm{LC}_{50}$ of a field population was greater than that of $\mathrm{BZ}$, relative resistance ratios of the field population were calculated using the $\mathrm{LC}_{50}$ value of the field population divided by the $\mathrm{LC}_{50}$ of $\mathrm{BZ}$. If the $\mathrm{LC}_{50}$ of a field population was less than that of BZ, the susceptibility ratio was calculated using the $\mathrm{LC}_{50}$ of $\mathrm{BZ}$ divided by the $\mathrm{LC}_{50}$ of the field population with a negative sign. In addition, dose-response data from Vip3Aa20 bioassays with the 12 populations collected from non-Bt corn fields during 2018 were pooled. The pooled data were then analyzed using probits to calculate the $\mathrm{LC}_{99}$ (the Vip3Aa20 concentration that caused 99\% mortality) and its $95 \%$ CI. The estimated $95 \%$ CIs of the $\mathrm{LC}_{99}$ were considered as a potential diagnostic concentration range to identify resistant individuals in field populations of $H$. zea.

As mentioned above, the 13 populations collected from Bt plants during the two years involved crop varieties expressing four different combinations of Bt proteins. Notably, only a single population was collected from each of SMT, Intra, and WS3 crop varieties. In addition, the Cry1 proteins (e.g., Cry1Ab, Cry1Ac, Cry1F, and Cry1A.105) expressed in the Bt crops have similar modes of action and are cross-resistant to each other in lepidopteran species including $H$. zea. Thus, in this study all the populations collected from the four types of Bt crop fields were considered as one group and then Student's $t$-tests (SAS PROC TTEST) [53] were used to compare the mean susceptibility data of the population group from non-Bt fields. Similarly, t-tests were also conducted to determine if there were significant differences in the Bt susceptibilities between the population groups collected between 2018 and 2019. In the $t$-tests, a population within an insect group was considered as a replication of the group. Based on the results of bioassays with Cry $1 \mathrm{Ab}$ toxin, the concentration of $10 \mu \mathrm{g} / \mathrm{cm}^{2}$ was chosen to discriminate Cry1Ab-resistant individuals from the insect populations, and, thus, mortality levels observed at $10 \mu \mathrm{g} / \mathrm{cm}^{2}$ were a better estimation of the actual susceptibility to Cry $1 \mathrm{Ab}$ than the estimated $\mathrm{LC}_{50}$ values for those populations with $<50 \%$ mortality at $10 \mu \mathrm{g} / \mathrm{cm}^{2}$. Thus, for bioassay data with Cry1 Ab, larval survivorship (\%) of field populations observed at $10 \mu \mathrm{g} / \mathrm{cm}^{2}$ of Cry1 Ab was corrected based on the control survival and the corrected mean survivorships at $10 \mu \mathrm{g} / \mathrm{cm}^{2}$ of Cry1Ab were used in the $t$-tests. In contrast, for the bioassays with Vip3Aa20, because $\mathrm{LC}_{50}$ values were able to be calculated for almost all the populations assayed, the calculated $\mathrm{LC}_{50}$ values were directly compared between the two groups of populations from non-Bt and Bt crops, and between the two groups of populations collected in 2018 and 2009. In addition, linear regressions (SAS PROC REG) [53] were also performed to test if there were significant relationships between the larval survivorships $(X)$ at $10 \mathrm{Cry} 1 \mathrm{Ab} \mu \mathrm{g} / \mathrm{cm}^{2}$ and the $\mathrm{LC}_{50}$ values $(\mathrm{Y})$ of Vip3Aa20 for the populations collected in 2018 (17 populations), 2019 (9 populations), and the full set of the 26 populations that were assayed against both Cry1Ab and Vip3Aa20 across both years. The reasons for the use of two different statistical 
criteria for the bioassays with the two Bt proteins in the regression analyses are the same as mentioned in the $t$-tests.

Author Contributions: Conceptualization, I.O., Y.Z., J.S.C., Z.W., and F.H.; methodology, Y.N., W.Y., S.L., M.D., S.B., F.P.F.R.-J., D.C., D.R., B.T., X.N., S.V.P.-M., and F.H.; writing-original draft preparation, Y.N. and F.H. All authors have reviewed, edited, and agreed to the published version of the manuscript. All authors have read and agreed to the published version of the manuscript.

Funding: This study was sponsored by Syngenta Crop Protection (Research Triangle Park, NC, USA), the Louisiana Soybean and Grain Research and Promotion Board. Hatch funds from the USDA National Institute of Food and Agriculture, and the USDA Multistate Research Project NC246.

Institutional Review Board Statement: Not applicable.

Informed Consent Statement: Not applicable.

Data Availability Statement: Not applicable.

Acknowledgments: This publication has been approved by the Associate Vice President \& Program Leader of the Louisiana State University Agricultural Center as manuscript No.: 2020-234-34933.

Conflicts of Interest: F.H. received research supports from Syngenta Crop Protection and Syngenta Crop Biotechnology for other studies. The authors declare that there is no conflict of interests regarding the publication of this article.

\section{References}

1. US EPA. White Paper on Resistance in Lepidopteran pests of Bacillus thuringiensis (Bt) Plant Incorporated Protectants in the United States. 2018. Available online: https://www.epa.gov/sites/production/files/2018-07/documents/position_paper_0713 2018.pdf (accessed on 22 December 2020).

2. Reay-Jones, F.P.F. Pest status and management of corn earworm (Lepidoptera: Noctuidae) in field corn in the United States. J. Integr. Pest Manag. 2019, 10, 1-9. [CrossRef]

3. National Agricultural Statistics Service (NASS). Acreage; USDA: Washington, DC, USA, 2020; ISBN 1949-1522. Available online: https:/ / www.nass.usda.gov/Publications/Todays_Reports/reports/acrg0620.pdf (accessed on 20 December 2020).

4. FIFRA Scientific Advisory Panel. Report of Subpanel on Bacillus thuringiensis (Bt) Plant-Pesticides and Resistance Management. EPA SAP Report; 1998. Available online: https://archive.epa.gov/scipoly/sap/meetings/web/pdf/finalfeb.pdf (accessed on 22 December 2020).

5. Sandstrom, M.A.; Changnon, D.; Flood, B.R. Improving our understanding of Helicoverpa zea migration in the Midwest: Assessment of source populations. Plant Health Prog. 2007, 8, 63. [CrossRef]

6. Dively, G.P.; Venugopal, P.D.; Finkenbinder, C. Field-evolved resistance in corn earworm to Cry proteins expressed by transgenic sweet corn. PLoS ONE 2016, 11, e0169115. [CrossRef] [PubMed]

7. Reisig, D.D.; Huseth, A.S.; Bacheler, J.S.; Aghaee, M.A.; Braswell, L.; Burrack, H.J.; Flanders, K.; Greene, J.K.; Herbert, D.A.; Jacobson, A. Long-term empirical and observational evidence of practical Helicoverpa zea resistance to cotton with pyramided Bt toxins. J. Econ. Entomol. 2018, 111, 1824-1833. [CrossRef] [PubMed]

8. Kaur, G.; Guo, J.; Brown, S.; Head, G.P.; Price, P.A.; Paula-Moraes, S.; Ni, X.; Dimase, M.; Huang, F. Field-evolved resistance of Helicoverpa zea (Boddie) to transgenic maize expressing pyramided Cry1A. 105/Cry2Ab2 proteins in northeast Louisiana, the United States. J. Invertebr. Pathol. 2019, 163, 11-20. [CrossRef]

9. Yang, F.; González, J.C.; Williams, J.; Cook, D.C.; Gilreath, R.T.; Kerns, D.L. Occurrence and ear damage of Helicoverpa zea on transgenic Bacillus thuringiensis maize in the field in Texas, US and its susceptibility to Vip3A protein. Toxins 2019, 11, 102. [CrossRef]

10. Storer, N.P.; Van Duyn, J.W.; Kennedy, G.G. Life history traits of Helicoverpa zea (Lepidoptera: Noctuidae) on non-Bt and Bt transgenic corn hybrids in eastern North Carolina. J. Econ. Entomol. 2001, 94, 1268-1279. [CrossRef]

11. Buntin, D.G.; All, J.N.; Lee, R.D.; Wilson, D.M. Plant-incorporated Bacillus thuringiensis resistance for control of fall armyworm and corn earworm (Lepidoptera: Noctuidae) in corn. J. Econ. Entomol. 2004, 97, 1603-1611. [CrossRef]

12. Reisig, D.D.; Reay-Jones, F.P.F. Inhibition of Helicoverpa zea growth by transgenic corn expressing Bt toxins. Environ. Entomol. 2015, 44, 1275-1285. [CrossRef]

13. Estruch, J.J.; Warren, G.W.; Mullins, M.A.; Nye, G.J.; Craig, J.A.; Koziel, M.G. Vip3A, a novel Bacillus thuringiensis vegetative insecticidal protein with a wide spectrum of activities against lepidopteran insects. Proc. Natl. Acad. Sci. USA 1996, 93, 5389-5394. [CrossRef]

14. Lee, M.K.; Walters, F.S.; Hart, H.; Palekar, N.; Chen, J.S. The mode of action of the Bacillus thuringiensis vegetative insecticidal protein Vip3A differs from that of Cry1Ab $\delta$-endotoxin. Appl. Environ. Microbiol. 2003, 69, 4648-4657. [CrossRef] [PubMed] 
15. Jackson, R.E.; Marcus, M.A.; Gould, F.; Bradley, J.R., Jr.; Van Duyn, J.W. Cross-resistance responses of Cry1Ac-selected Heliothis virescens (Lepidoptera: Noctuidae) to the Bacillus thuringiensis protein Vip3A. J. Econ. Entomol. 2007, 100, 180-186. [CrossRef] [PubMed]

16. Niu, Y.; Yang, F.; Dangal, V.; Huang, F. Larval survival and plant injury of Cry1F-susceptible, -resistant, and -heterozygous fall armyworm (Lepidoptera: Noctuidae) on non-Bt and Bt corn containing single or pyramided genes. Crop Prot. 2014, 59, 22-28 [CrossRef]

17. Santos-Amaya, O.F.; Rodrigues, J.V.; Souza, T.C.; Tavares, C.S.; Campos, S.O.; Guedes, R.N.; Pereira, E.J. Resistance to dual-gene Bt maize in Spodoptera frugiperda: Selection, inheritance, and cross-resistance to other transgenic events. Sci. Rep. 2015, 5, 18243. [CrossRef] [PubMed]

18. Chakroun, M.; Banyuls, N.; Bel, Y.; Escriche, B.; Ferré, J. Bacterial vegetative insecticidal proteins (VIP) from entomopathogenic bacteria. Microbiol. Mol. Biol. Rev. 2016, 80, 329-350. [CrossRef] [PubMed]

19. US-EPA (US Environmental Protection Agency). Biopesticides Registration Action Document: Bacillus thuringiensis Vip3Aa20 Insecticidal Protein and the Genetic Material Necessary for Its Production (via Elements of Vector pNOV1300) in Event MIR162 Maize. 2009. Available online: https://www3.epa.gov/pesticides/chem_search/reg_actions/registration/decision_PC-0065 99_3-Apr-09.pdf (accessed on 24 April 2020).

20. Ali, M.I.; Luttrell, R.G. Susceptibility of Helicoverpa zea and Heliothis virescens (Lepidoptera: Noctuidae) to Vip3A insecticidal toxin expressed in VipCot ${ }^{\mathrm{TM}}$ cotton. J. Invertebr. Pathol. 2011, 108, 76-84. [CrossRef]

21. Burkness, E.C.; Dively, G.; Patton, T.; Morey, A.C.; Hutchison, W.D. Novel Vip3A Bacillus thuringiensis (Bt) maize approaches high-dose efficacy against Helicoverpa zea (Lepidoptera: Noctuidae) under field conditions. GM Crop. 2010, 1, 1-7.

22. Palekar, N.; Kurtz, R.W.; Walters, F.S.; O'Reilly, D. Relative efficacy of cotton events expressing Cry1Ab and Vip3A against cotton bollworm and tobacco budworm (Lepidoptera: Noctuidae). J. Cotton Sci. 2011, 15, 100-108.

23. Yang, F.; Kerns, D.L.; Leonard, B.R.; Oyediran, I.; Burd, T.; Niu, Y.; Huang, F. Performance of Agrisure ${ }^{\circledR V i p t e r a}{ }^{\mathrm{TM}} 3111$ corn against Helicoverpa zea (Lepidoptera: Noctuidae) in seed mixed plantings. Crop Prot. 2015, 69, 77-82. [CrossRef]

24. Dimase, M.; Oyediran, I.; Brown, S.; Walker, W.; Guo, J.; Yu, W.; Zhang, Y.; Chen, J.; Wen, Z.; Huang, F. Larval movement and survival of Helicoverpa zea (Boddie) in seed blends of non-Bt and Bt maize containing Agrisure Viptera ${ }^{\circledR}$ trait: Implications for resistance management. Crop Prot. 2020. [CrossRef]

25. Guo, J.; Oyediran, I.; Rice, M.E.; Brown, S.; Dimase, M.; Lin, S.; Walker, W.; Yu, W.; Niu, Y.; Huang, F. Seed blends of pyramided Cry/Vip maize reduce Helicoverpa zea populations from refuge ears. J. Pest Sci. 2020. [CrossRef]

26. Huang, F. Resistance of the fall armyworm, Spodoptera frugiperda (J. E. Smith), to transgenic Bacillus thuringiensis Cry1F corn in the Americas: Lessons and implications for Bt corn IRM in China. Insect Sci. 2020. [CrossRef] [PubMed]

27. Storer, N.P.; Babcock, J.M.; Schlenz, M.; Meade, T.; Thompson, G.D.; Bing, J.W.; Huckaba, R.M. Discovery and characterization of field resistance to Bt maize: Spodoptera frugiperda (Lepidoptera: Noctuidae) in Puerto Rico. J. Econ. Entomol. 2010, 103, 1031-1038. [CrossRef] [PubMed]

28. Farias, J.R.; Andow, D.A.; Horikoshi, R.J.; Sorgatto, R.J.; Fresia, P.; Santos, A.C.; Omoto, C. Field-evolved resistance to Cry1F maize by Spodoptera frugiperda (Lepidoptera: Noctuidae) in Brazil. Crop Prot. 2014, 64, 150-158. [CrossRef]

29. Huang, F.; Qureshi, J.A.; Meagher, R.L., Jr.; Reisig, D.D.; Head, G.P.; Andow, D.A.; Ni, X.; Kerns, D.; Buntin, G.D.; Niu, Y.; et al. Cry1F resistance in fall armyworm Spodoptera frugiperda: Single gene versus pyramided Bt maize. PLoS ONE 2014, 9, e112958. [CrossRef]

30. Chandrasena, D.; Signorini, A.M.; Abratti, G.; Storer, N.G.; Olaciregui, M.L.; Alves, A.P.; Pilcher, C.D. Characterization of field-evolved resistance to Bacillus thuringiensis derived Cry1F反 endotoxin in Spodoptera frugiperda populations from Argentina. Pest Manag. Sci. 2018, 74, 746-754. [CrossRef]

31. Leite, N.A.; Pereira, R.M.; Durigan, M.R.; Amado, D.; Fatoretto, J.; Medeiros, F.C.L.; Omoto, C. Susceptibility of Brazilian populations of Helicoverpa armigera and Helicoverpa zea (Lepidoptera: Noctuidae) to Vip3Aa20. J. Econ. Entomol. 2018, 111, 399-404. [CrossRef]

32. Huang, F. Detection and monitoring of insect resistance to transgenic Bt crops. Insect Sci. 2006, 13, 73-84. [CrossRef]

33. Luttrell, R.G.; Wan, L.; Knighten, K. Variation in susceptibility of noctuid (Lepidoptera) larvae attacking cotton and soybean to purified endotoxin proteins and commercial formulations of Bacillus thuringiensis. J. Econ. Entomol. 1999, 92, 21-32. [CrossRef]

34. Siegfried, B.D.; Spencer, T.; Nearman, J. Baseline susceptibility of the corn earworm (Lepidoptera: Noctuidae) to the Cry1Ab toxin from Bacillus thuringiensis. J. Econ. Entomol. 2000, 93, 1265-1268. [CrossRef]

35. Anilkumar, K.J.; Rodrigo-Simón, A.; Ferré, J.; Pusztai-Carey, M.; Sivasupramaniam, S.; Moar, W.J. Production and characterization of Bacillus thuringiensis Cry1Ac-resistant cotton bollworm Helicoverpa zea (Boddie). Appl. Environ. Microbiol. 2008, 74, 462-469. [CrossRef] [PubMed]

36. Welch, K.L.; Unnithan, G.C.; Degain, B.A.; Wei, J.; Zhang, J.; Li, X.; Tabashnik, B.E.; Carrière, Y. Cross-resistance to toxins used in pyramided Bt crops and resistance to Bt sprays in Helicoverpa zea. J. Invertebr. Pathol. 2015, 132, 149-156. [CrossRef] [PubMed]

37. Tabashnik, B.E.; Carrière, Y. Evaluating Cross-resistance Between Vip and Cry Toxins of Bacillus thuringiensis. J. Econ. Entomol. 2020, 113, 553-561. [CrossRef] [PubMed]

38. Luttrell, R.G.; Jackson, R.E. Helicoverpa zea and Bt cotton in the United States. GM Crops Food 2012, 3, 213-227. [CrossRef] 
39. Siebert, M.W.; Nolting, S.P.; Hendrix, W.; Dhavala, S.; Craig, C.; Leonard, B.R.; Stewart, S.D.; All, J.; Musser, F.R.; Buntin, G.D.; et al. Evaluation of corn hybrids expressing Cry1F, Cry1A. 105, Cry2Ab2, Cry34Ab1/Cry35Ab1, and Cry3Bb1 against southern United States insect pests. J. Econ. Entomol. 2012, 105, 1825-1834. [CrossRef]

40. Rule, D.M.; Nolting, S.P.; Prasifka, P.L.; Storer, N.P.; Hopkins, B.W.; Scherder, E.F.; Siebert, M.W.; Hendrix, W.H., III. Efficacy of pyramided Bt proteins Cry1F, Cry1A.105, and Cry2Ab2 expressed in SmartStax corn hybrids against lepidopteran insect pests in the northern United States. J. Econ. Entomol. 2014, 107, 403-409. [CrossRef]

41. Bilbo, T.R.; Reay-Jones, F.P.; Reisig, D.D.; Greene, J.K. Susceptibility of corn earworm (Lepidoptera: Noctuidae) to Cry1A. 105 and Cry2Ab2 in North and South Carolina. J. Econ. Entomol. 2019, 112, 1845-1857. [CrossRef]

42. Yu, W.; Lin, S.; Dimase, M.; Niu, Y.; Brown, S.; Head, G.P.; Price, P.A.; Reay-Jones, F.P.F.; Cook, D.; Reisig, D.; et al. Extended investigation of the field-evolved resistance of the corn earworm (Lepidoptera: Noctuidae) to Bacillus thuringiensis Cry1A.105 and Cry2Ab2 proteins in the southeastern United States. J. Invertebr. Path. 2021. submitted.

43. Adamczyk, J.J.; Mahaffey, J.S. Efficacy of Vip3A and Cry1Ab transgenic traits in cotton against various lepidopteran pests. Fla. Entomol. 2008, 91, 570-575.

44. Bommireddy, P.L.; Leonard, B.R.; Temple, J.; Price, P.; Emfinger, K.; Cook, D.; Hardke, J.T. Field performance and seasonal efficacy profiles of transgenic cotton lines expressing Vip3A and VipCot against Helicoverpa zea (Boddie) and Heliothis virescens (F.). J. Cotton Sci. 2011, 15, 251-259.

45. Hernández-Rodríguez, C.S.; Hernández-Martínez, P.; Van Rie, J.; Escriche, B.; Ferré, J. Shared midgut binding sites for Cry1A.105, Cry1Aa, Cry1Ab, Cry1Ac and Cry1Fa proteins from Bacillus thuringiensis in two important corn pests, Ostrinia nubilalis and Spodoptera frugiperda. PLoS ONE 2013, 8, e68164. [CrossRef] [PubMed]

46. Bernardi, D.; Salmeron, E.; Horikoshi, R.J.; Bernardi, O.; Dourado, P.M.; Carvalho, R.A.; Martinelli, S.; Head, G.P.; Omoto, C. Cross-resistance between Cry1 proteins in fall armyworm (Spodoptera frugiperda) may affect the durability of current pyramided Bt maize hybrids in Brazil. PLoS ONE 2015, 10, e0140130. [CrossRef] [PubMed]

47. Niu, Y.; Head, G.P.; Price, P.A.; Huang, F. Performance of Cry1A.105-selected fall armyworm (Lepidoptera: Noctuidae) on transgenic maize plants containing single or pyramided Bt genes. Crop Prot. 2016, 88, 79-87. [CrossRef]

48. Vyavhare, S.S.; Kerns, D. Bt cotton. Texas AgriLife Extension. ENTO-067. 2017. Available online: http://lubbock.tamu.edu/files/ 2017/03/Bt-Cotton_ENTO067.pdf (accessed on 24 April 2020).

49. DiFonzo, C. The Handy Bt Trait Table for U.S. Corn Production. 2020. Available online: https://agrilife.org/lubbock/files/2020 /02/BtTraitTable_FEB_2020.pdf (accessed on 22 December 2020).

50. Huang, F.; Leonard, B.R.; Gable, R.H. Comparative susceptibility of European corn borer, southwestern corn borer, and sugarcane borer (Lepidoptera: Crambidae) to Cry1Ab protein in a commercial Bt-corn hybrid. J. Econ. Entomol. 2006, 99, 194-202. [CrossRef]

51. Abbott, W.S. A method of computing the effectiveness of an insecticide. J. Econ. Entomol. 1925, 18, 265-267. [CrossRef]

52. Finney, D.J. Probit Analysis; Cambridge University Press: Cambridge, UK, 1971.

53. SAS Institute. SAS/STAT User's, 3rd ed.; SAS Institute Inc.: Cary, NC, USA, 2010. 